\title{
MAS NÃO SOU FORMADO EM MÚSICA... E AGORA? POSSIBILIDADES MUSICAIS NA EDUCAÇÃO INFANTIL
}

Lidiane Cristina Loiola Souza ${ }^{\mathrm{i}}$

\section{Introdução}

Música... Explorar... Criar... Tocar... Como essas situações podem ser possíveis na Educação Infantil?

O presente trabalho traz um relato de experiência referente às possibilidades musicais em uma sala de aula da Educação Infantil, em uma escola municipal da cidade de São Paulo, com a intenção de mostrar que, mesmo sem formação específica na área, o professor poderá promover a exploração, a escuta ativa e a atividade criativa com sons e ritmos, contribuindo para a prática musical com crianças na idade de cinco e seis anos. O relato é pautado à luz de pesquisadores que abordam a temática, sendo o tema, nessa perspectiva, relevante para a Educação, por apresentar ações que tornam a música acessível a essas crianças.

A escolha por esse assunto aconteceu em função de questionamentos decorrentes da aprovação da lei 11.769 de 18 de agosto de 2008, que inclui o ensino de música nas escolas, e devido a vivências e reflexões advindas de cursos de formação variados e no Curso de Especialização em Linguagens da Arte no Centro Universitário Maria Antônia, no qual tive a oportunidade de ter aulas com os professores de música Pedro Paulo Salles e Fábio Cintra. Diante de tantas informações novas, tive meu olhar ampliado frente ao tema e, também, pude perceber que seria possível um trabalho musical junto às crianças.

Assim, a pesquisa de campo na classe em que leciono e a consulta a determinadas referências bibliográficas se fizeram necessárias e colaboraram para a ponderação sobre a pertinência e o significado das ações empreendidas em sala de aula - que tiveram a intenção de viabilizar uma prática musical na escola - por um professor generalista, sem formação específica nessa linguagem artística. Nesse sentido, procuro discutir as seguintes questões em meu trabalho: Como se dá o fazer musical na Educação Infantil? Um professor sem formação específica consegue trabalhar música com as crianças? Quais as possibilidades de se trabalhar música na Educação Infantil?

A pesquisa buscou entender como se dá o fazer musical no contexto da Educação Infantil, considerando que a música faz parte da vida da criança, antes mesmo de ela nascer.

Atenta, ainda, para o fato de que esta (a criança), ao entrar na escola, depara-se com a 
utilização da música, muitas vezes, feita de modo estereotipado, repetitivo e sem significado. Em muitas escolas, há momentos em que a música marca ações rotineiras (lavar as mãos e hora do lanche, por exemplo) e, outros, em que alude a datas comemorativas.

Deparamo-nos, ainda, com uma realidade em que a maioria dos professores não tem formação específica na área musical. Ressalto que este também é o meu caso, pois sou formada em Artes Visuais e me vi muitas vezes com dificuldades em relação ao trabalho com música.

Foi possível verificar que a intervenção feita na sala de aula, em que proponho que as crianças explorem, criem, toquem e vivenciem uma infinidade de sons e ritmos, trouxe elementos e possibilidades viáveis à prática musical na escola. No entanto, é preciso destacar que as atitudes tomadas por mim contribuíram para isso, pois o professor deve estar sempre disposto a aprender, a pesquisar e a ampliar suas próprias preferências musicais, a fim de promover esse acesso a seus alunos.

\section{O fazer musical na Educação Infantil}

"Perceber, produzir e relacionar-se com e por meio de sons faz parte da história de vida de todos nós".

(BRITO, 2003)

A música se faz presente em nossas vidas, em acontecimentos pessoais e nas relações com os outros, antes mesmo de nascermos, pois diferentes ambientes sonoros nos circundam, desde a gestação. As crianças iniciam suas vivências musicais ainda na barriga da mãe e crescem em meio a sons característicos do seu cotidiano e contexto sociocultural. BRITO (2003, p. 35) destaca que temos um repertório musical especial, constituído por músicas significativas que dizem respeito à nossa história de vida.

\footnotetext{
Os bebês e as crianças interagem permanentemente com o ambiente sonoro que os envolve e - $\operatorname{logo}$ - com a música, já que ouvir, cantar e dançar são atividades presentes na vida de quase todos os seres humanos, ainda que de diferentes maneiras. Podemos dizer que o processo de musicalização dos bebês e crianças começa espontaneamente, de forma intuitiva, por meio do contato com toda a variedade de sons do cotidiano, incluindo aí a presença da música (BRITO, 2003, p. $35)$.
}

A criança, ao entrar na Educação Infantil (primeira etapa de escolarização), estará inserida em um universo musical. Entretanto, de acordo com BRITO (2003, p. 51), este universo é rodeado de muitos resquícios onde a utilização da música é um suporte para a aquisição de conhecimentos gerais, na intenção de formar hábitos e atitudes, rotina e 
comemoração de datas diversas. Além disso, a música vem acompanhada por gestos e movimentos repetitivos e estereotipados.

Atendendo a demanda da lei 11.769, sancionada em 18 de Agosto de 2008, que inclui o ensino de música na grade curricular em todas as escolas de educação básica, fazem-se necessárias ações que tornem significativa a presença da música na escola, segundo princípios específicos dessa linguagem, e não como uma forma de expressão empobrecida e a serviço de outras áreas.

Pensando em alternativas e instrumentos acessíveis que contribuam para a realização de um trabalho com música na Educação Infantil, a música pode ser explorar diferentes fontes sonoras, utilizar de instrumentos musicais convencionais ou não, como por exemplo: sons com o corpo, com a voz ou ainda utilizar objetos do cotidiano.

Por sua vez, o professor pode buscar conhecer concepções educacionais e de ensino de música que contemplem uma atuação efetiva em uma etapa tão importante como a Educação Infantil, marcada por estímulos importantes que se refletirão por toda a vida do educando.

FONTERRADA (2008, p. 236) afirma ser na primeira infância a construção de todas as bases sensoriais, afetivas, mentais, morais, sociais e estéticas que nortearão as fases posteriores, e BRITO (2003, p. 35) destaca que a criança é um ser "brincante" e brincando também se faz música:

[...] as cantigas de ninar, as canções de roda, as parlendas e todo tipo de jogo musical têm grande importância, pois é por meio das interações que se estabelecem que os bebês desenvolvem um repertório que lhes permitirá comunicar-se pelos sons; os momentos de troca e comunicação sonoro-musicais favorecem o desenvolvimento afetivo e cognitivo, bem como a criação de vínculos fortes tanto com os adultos quanto com a música (BRITO 2003, p. 35).

SCHAFER (2011, p. 272) ressalta a necessidade de promover as potencialidades criativas das crianças, para que possam, dessa forma, fazer músicas por si mesmas. E SALLES (2002, p. 39) destaca que, a partir do início do século XX, a criança passa a ser considerada pelas correntes da pedagogia musical, surgidas naquele período, como um ser pensante, com ideias próprias e pessoais e com um potencial inesgotável de aprendizagem.

O Referencial Curricular Nacional para a Educação Infantil (1998) salienta:

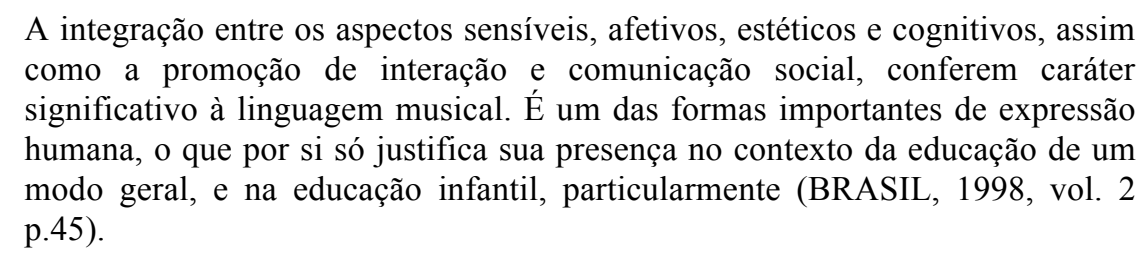

O mesmo Referencial Curricular ressalta: 
[...] para que a aprendizagem da música possa ser fundamental na formação do cidadão, é necessário que todos tenham a oportunidade de participar ativamente como ouvintes, intérpretes, compositores e improvisações, dentro e fora da sala de aula. Isso exige que atividades musicais, estejam inseridas nas práticas educativas dos professores (BRASIL, 1998, p. 103)

Nessa perspectiva, o ensinar e aprender música não se restringe apenas a quem domina o conceito. O próprio Referencial Curricular destaca que a música é, de fato, parte importante da formação humana, que todas as crianças devem ter acesso à educação musical e que a escola é o elo para tal finalidade, pois na medida em que a criança "experimenta" atividades musicais, cria intimidade com o universo sonoro e amplia o seu repertório.

No prefácio do livro Música na Educação Infantil, de Teca Alencar de Brito, Judith Akoschky sinaliza que a educação musical para aquela autora é um "processo contínuo de aprendizagem que envolve perceber, sentir, experimentar, criar e refletir" (BRITO, 2003, p. 9).

\section{1 - Mas não sou formada em música... E agora?}

"O novo educador incentivará os sons à vida humana” (SCHAFER, 1991, p.295)

O professor tem a possibilidade de buscar formação, cursos e capacitações no intuito de promover às crianças o contato com a educação musical, desenvolvendo, dessa forma, melhor compreensão das propostas, atuando adequadamente e promovendo não só o contato com a música, mas a ação e transformação acerca dela. Segundo FONTERRADA (2008, p.274), a escola dispõe de um espaço ideal para o fazer musical e, também, que "é preciso resgatar o professor que, mesmo não sendo músico, goste de música e a traga para dentro da escola."

Dessa forma, é necessário aguçar o gosto e o conhecimento musical do professor, estimulando-o a adotar essa linguagem em sua trajetória docente e favorecendo seu interesse em proporcionar às crianças situações musicais lúdicas, prazerosas e desafiadoras. Nessa perspectiva, BRITO (2003, p. 45) se coloca:

\footnotetext{
Obviamente, respeitar o processo de desenvolvimento da expressão musical infantil não deve se confundir com a ausência de intervenções educativas. Nesse sentido, o professor deve atuar - sempre - como animador, estimulador, provedor de informações e vivências que irão enriquecer e ampliar a experiência e o conhecimento das crianças, não apenas do ponto de vista musical, mas integralmente, o que deve ser o objetivo prioritário de toda proposta pedagógica, especialmente na etapa da educação infantil.
} 
E conclui:

Entretanto, é importante considerar legítimo o modo como as crianças se relacionam com os sons e silêncios, para que a construção do conhecimento ocorra em contextos significativos, que incluam criação, elaboração de hipótese, descobertas, questionamentos, experimentos etc (BRITO 2003, p. 45).

Um professor curioso em relação à música tem a possibilidade de ampliar as preferências musicais pessoais, não deixando velhos hábitos arraigarem-se, mas adquirindo novas formas de atuar e permitindo-se sempre descobrir coisas novas. Por sua vez, KOELLREUTTER (1987, p. 8) salienta que o professor deve se encorajar a ter novas experiências.

Desse modo, ao considerar fazeres musicais que possam ser colocados em prática por um professor que não tem formação específica em educação musical, FONTERRADA (2011, p.276) aponta que, embora haja questões que exijam conhecimentos específicos e próprios das ações dos especialistas, "há muitas atividades que o professor não músico pode desenvolver com sua classe, com o objetivo de estimular o gosto pela música; sem dúvida, é possível cantar e tocar, mesmo que o professor não saiba ler música”.

A autora afirma que tal professor não necessita de formação específica, mas de musicalidade e de interesse pela música e pelos sons, buscando bibliografias e materiais que possam auxiliá-lo em sua prática. O professor pode propor uma diversidade de situações musicais ricas e significativas, e ainda inventar novas formas de brincar e tocar músicas, procurando favorecer a expressão criativa e prazerosa da criança proporcionando o experimentar e o fazer musical contribuindo para o processo de criação e recriação. Dessa forma, o professor poderá criar um ambiente rico de possibilidades que proporcionem novas experiências às crianças.

\section{2 - Possibilidades musicais na educação musical}

"O universo é nossa orquestra" Schafer (2011, p. 181)

Trago neste capítulo, possibilidades musicais acerca de minha prática em sala de aula na intenção de contribuir com experiências musicais diversas. Na EMEI em que leciono, realizo muitos trabalhos por projetos, sendo que um deles teve a intenção de promover possibilidades de exploração musical. 
A respeito de trabalhos por projetos, HERNANDEZ (2000, p. 179) destaca:

Quando falamos em projetos, o fazemos pelo fato de imaginarmos que possam ser um meio de ajudar-nos a repensar e refazer a escola. Entre outros motivos, porque, por meio deles, estamos reorganizando a gestão do espaço, do tempo, da relação entre os docentes e os alunos, sobretudo porque nos permite redefinir o discurso sobre o saber escolar (aquilo que regula o que se vai ensinar e como devemos fazêlo).

Nessa perspectiva, o trabalho por projetos torna professor e criança protagonistas no processo, pois ambos participam intensamente das aprendizagens proporcionadas, em que são criados novos tipos de relações e incentivadas a busca e a descoberta voltadas à construção e à reconstrução constantes do conhecimento.

Tenho formação em Artes Visuais e a linguagem musical sempre foi pouco familiar em minha prática; não me sentia segura ao realizar um trabalho com música frente às crianças. Participar do curso de Especialização em Linguagens da Arte e ter tido o contato com as aulas do Prof. Pedro Paulo Salles e com o Prof. Fábio Cintra ampliaram o meu olhar diante da música e me fizeram compreender que é possível realizar um trabalho musical de qualidade junto às crianças, mesmo sem uma formação específica em música.

Ultimamente, além de participar de cursos de formação docente, voltados à ampliação das práticas musicais com crianças, de forma que as mesmas pudessem inventar novas formas de brincar e tocar música, favorecendo a expressão criativa e prazerosa tanto no âmbito da apreciação quanto da produção, tenho realizado uma vasta pesquisa bibliográfica e na internet.

Em SALLES (2002, p.110), ao pesquisar sobre nossa atuação e transformação sobre os sons do mundo, verifiquei que há várias formas de se trabalhar a escuta ativa:

[...] explorando os sons ambientes, explorando objetos sonoros, expressando os sons através de movimentos corporais e cênicos, imaginando o som e criando histórias, desenhos, grafias e buscando material sonoro para composição. Todas essas formas devem estar atreladas a projetos planejados juntamente com as crianças, seja na forma de um projeto científico, de um projeto musical ou de uma situação lúdica, ou ainda de uma situação em que estão envolvidas a imaginação, a narrativa e a fantasia.

Dessa forma, o projeto "Possibilidades Musicais na Educação Infantil: paisagem sonora, corpo, voz, objetos, e espaços de criação e exploração musical. Uma realidade possível?" colocado em prática com crianças entre cinco e seis anos teve como objetivos:

- Promover a escuta e a percepção ativa dos sons do meio (paisagem sonora); 
- Ampliar o repertório musical das crianças;

- Explorar os parâmetros do som (timbre, altura, intensidade e duração);

- Explorar sons e ritmos de materiais diversos e através de diferentes formas de manipulação;

- Possibilitar a exploração e a construção de diferentes instrumentos musicais feitos com sucata e a expressão musical por meio deles;

- Explorar sons, ritmos e diferentes combinações sonoras a partir do próprio corpo;

- Proporcionar situações de aprendizagem, envolvendo a exploração da voz e a criação de brincadeiras musicais.

\section{3 - Etapas do projeto}

\subsection{Paisagem sonora}

O projeto teve início com a exploração da paisagem sonora dos ambientes da escola: corredor, sala de aula, pátio, parque e refeitório. O termo paisagem sonora foi criado pelo compositor canadense Murray Schafer: "uma paisagem é um conjunto de sons ouvidos num determinado lugar" SCHAFER (2011, p.201).

Inicialmente, foi solicitado às crianças que ouvissem os sons à sua volta nos diferentes espaços da escola a fim de seguir a proposta de SCHAFER (2011), que nos coloca que o mundo está cheio de sons e que, para percebermos aquelas sonoridades que nem sempre notamos, é preciso escutar avidamente os sons dos ambientes que costumamos frequentar.

De acordo com as observações feitas, as crianças tiveram a oportunidade de perceber que há sons por toda parte e, após essa escuta atenta, puderam relatar o que ouviram na roda de conversa e registrar os sons através de desenho. Dessa forma, destaquei a elas que é possível ouvir sons em diferentes lugares e não só com um instrumento musical, pois o mundo é cheio de sons que podem ser ouvidos por toda parte (SCHAFER, 2011).

Construímos, assim, um mapa dos diferentes lugares da escola por meio de um registro gráfico dos sons ouvidos durante o trajeto. 


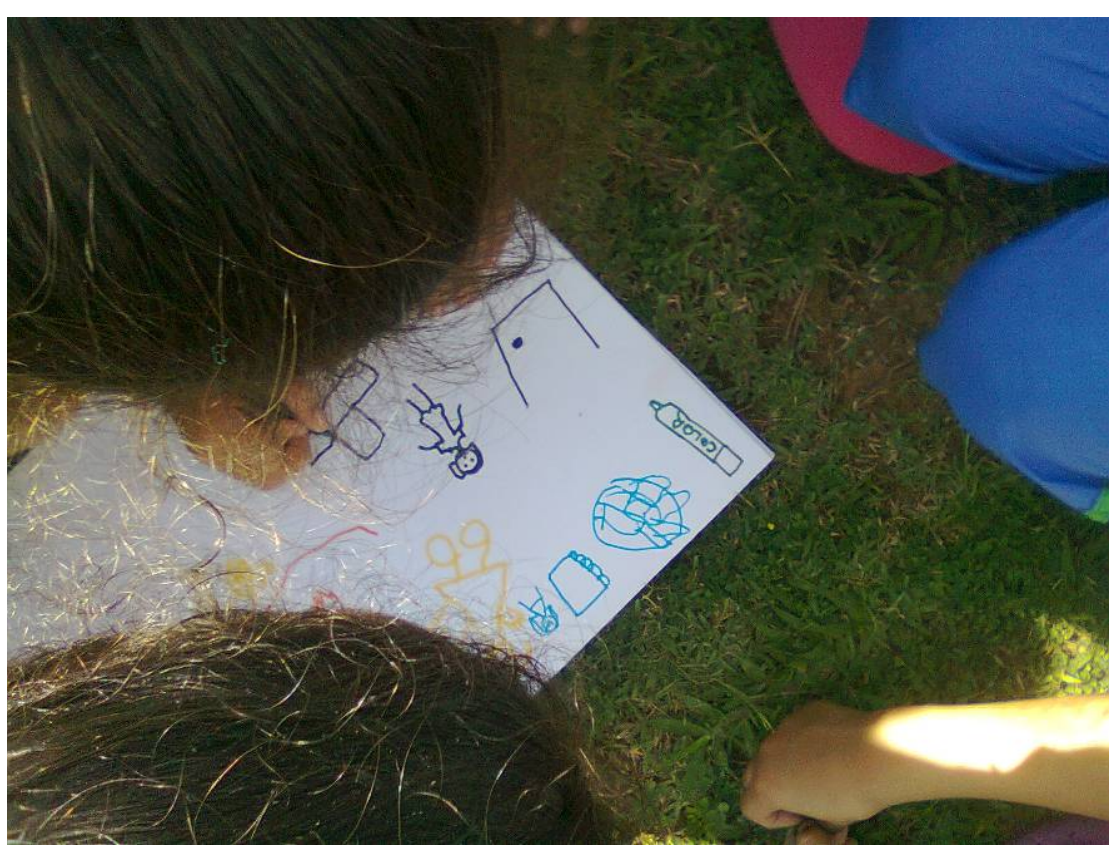

Figura 1 - Construção coletiva de um mapa sonoro dos espaços da escola

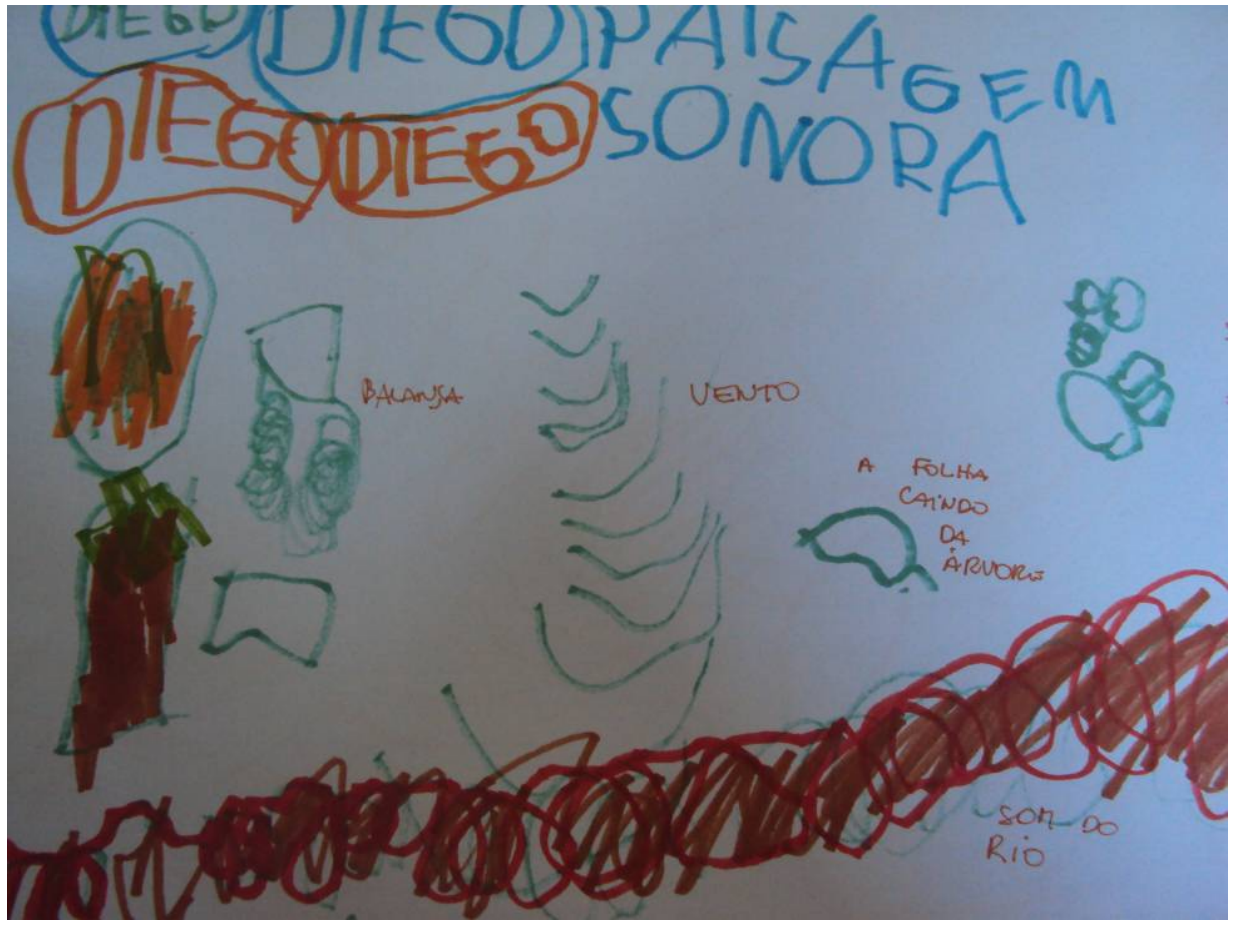

Figura 2 desenho feito por uma criança da paisagem sonora

Cabe mencionar, aqui, que o Referencial Curricular Nacional para a Educação Infantil (RCNEI) ressalta a importância desse tipo de registro, em que é feita a representação do que o ouvido percebeu (MEC 1998, p. 75).

\subsection{Exploração sonora de objetos e instrumentos}

No momento seguinte, exploramos os objetos do cotidiano e os sons que esses objetos poderiam produzir, ressaltando que instrumentos não convencionais também trazem 
possibilidades de criação de sons e ritmos. As crianças foram convidadas a explorar os objetos da própria sala de aula, na intenção de perceber as possibilidades sonoras dos objetos e, também, de compreender a infinidade de fontes sonoras existentes do ambiente pesquisado. Segundo BRITO (2003, p. 59), fonte sonora pode ser descrita como "todo e qualquer material produtor ou propagador de sons", sejam eles produzidos pelo corpo, por objetos ou por instrumentos musicais diversos. A partir disso foi possível concluir que é possível fazer música com todo e qualquer material capaz de produzir som.

Escolhidos os objetos e suas sonoridades, as crianças foram estimuladas a reproduzirem um som com o uso dos objetos escolhidos durante a exploração e pesquisa. Houve crianças que produziram sons batendo um objeto no outro, outras utilizando as mãos, ou ainda batendo o objeto no chão. Além de reproduzir, foi contemplada a ação de ouvir os sons realizados pelos colegas, de modo atento e organizado. As crianças ficaram sentadas em uma grande roda dentro da sala e uma a cada vez foi convidada a mostrar o som produzido.

A respeito da experiência com objetos sonoros, PACHECO (2007) nos diz:

O trabalho com materiais alternativos, materiais que não foram originalmente concebidos para produzir som, propõe para os seus participantes uma atuação que implica um exercício de pesquisa e de criatividade. Tocar, fazer música com material alternativo exige que se procure, que se investigue, buscando possibilidades sonoras. Aprender a tocar um instrumento não significa somente dominar as técnicas de execução sob a orientação de alguém, mas, sim, inventar formas de executar. Esse exercício torna essa procura, essa pesquisa, uma possibilidade real de construção de conhecimento musical (,p.92).

\subsection{Seleção e organização de sons}

Em seguida, brincamos de "Você é o maestro". Expliquei às crianças qual era a função de um maestro na orquestra: organizar os sons que serão produzidos em função da obra a ser executada. Primeiro, fiz uma vez para que as crianças pudessem entender a ação de apontar com as mãos ou os dedos para cada grupo de sons dos objetos escolhidos pelas crianças; depois elas foram convidadas a atuarem como o maestro e muitas crianças experimentaram a brincadeira, de forma divertida.

No momento seguinte, para ampliar o repertório das crianças acerca das diferentes possibilidades musicais, apresentei a elas vídeos dos grupos $S T O M P^{i i}$ e Barbatuques $^{i i i}$, para que pudessem apreciar tanto a criação de sons com objetos do cotidiano, como a exploração 
sonora com o corpo e com a voz. As crianças perceberam infinitas possibilidades sonoras que podem ser criadas e desenvolvidas.

Ao explorarem sons com a voz, trabalhamos diferentes entonações, sons mais fortes ou fracos, uso de vogais, movimentos com a boca e a língua, sílabas, onomatopeias e repetições.

Com o corpo, a produção de sons explorando diferentes partes do corpo tais como: mãos (bater palmas de diferentes formas, estalar os dedos, bater com as mãos em diferentes partes do corpo - nas pernas, nos braços, nas coxas, na boca, com os pés).

Para ampliar essa situação de aprendizagem, a sala foi dividida em três grupos. Cada um deles recebeu o comando para produzir diferentes tipos de sons, utilizando mãos, boca, voz e outras partes do corpo. Deixei que cada grupo se organizasse, de forma autônoma, em relação a como seria a criação do som e a posterior apresentação em sala para os colegas. Durante as minhas observações durante o andamento da atividade, pude perceber o interesse das crianças pela organização, pela criatividade na experimentação e seleção do som, pela discussão entre eles para a escolha do gesto e do som produzido e pela culminância em lindas apresentações dentro da sala de aula para os próprios colegas de turma.

\subsubsection{Registro gráfico de sons}

Em uma roda de conversa, após as apresentações, comentei com as crianças sobre a função das partituras, usadas para organizar e registrar graficamente os sons de uma composição musical.

Criamos em conjunto uma partitura não tradicional (figura 3), com diferentes tipos de som (vocal, corporal, de objetos, dentre outros), escolhidos e dispostos graficamente pelas próprias crianças - estas, além de escolherem o som, destacaram a quantidade de vezes que ele deveria ser tocado. Na figura 3, é possível identificar o desenho da mão que indica palmas por duas ou três vezes. Esse registro partiu de uma criança que colocou o número 3 e a letra $X$ para demonstrar essa quantidade.

A ideia musical, ao realizar essa atividade, teve o objetivo de organizar os sons que os alunos criaram de forma a elaborar uma composição. Ao final, a visualização da sequência de desenhos registrados foi lida como uma peça musical e, finalmente, gravada em vídeo . 


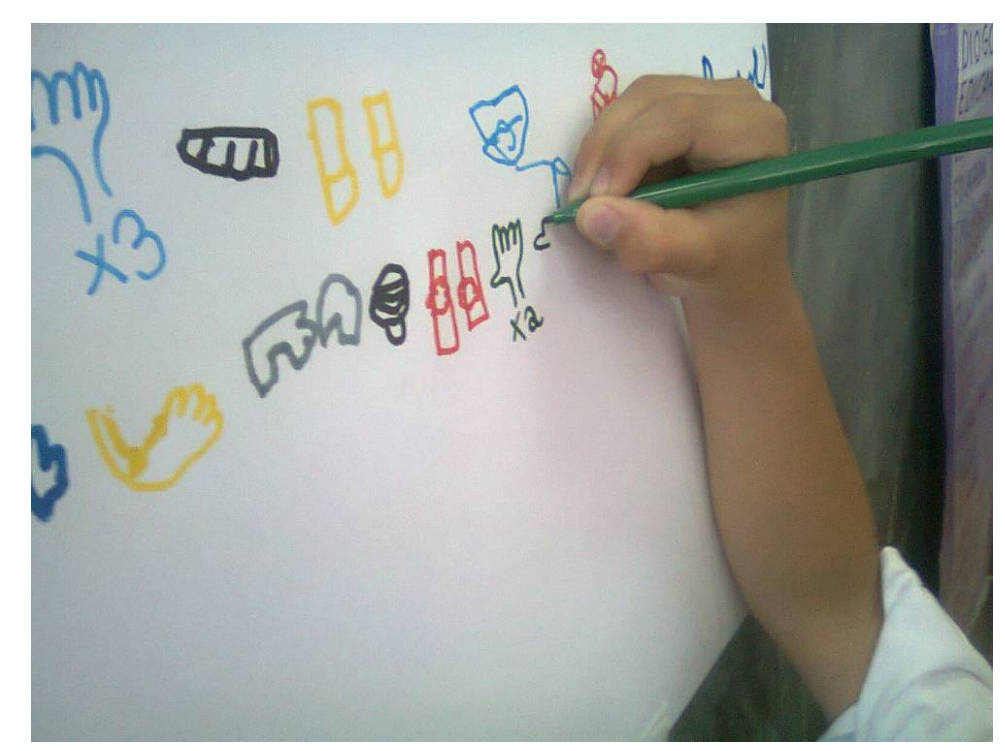

As crianças gostaram de criar partituras e, a partir dessa atividade, foi realizada outra, decorrente de um CD com a gravação de diferentes sons e ritmos. Solicitei que as crianças ouvissem as músicas e registrassem graficamente como seria aquele som em forma de desenho. Nessa perspectiva, Brito (2003, p.179) destaca:

\begin{abstract}
Desenhar o som, podemos considerar que um primeiro modo de notação de sons é trazer para o gesto gráfico aquilo que a percepção auditiva identificou. Partindo do registro gráfico intuitivo, chega-se à criação de códigos de notação que serão lidos, para serem decodificados pelo grupo, num processo sequencial que respeita níveis de percepção, cognição ensciência (BRITO,2003, p. 179).
\end{abstract}

\title{
3.1.5 Criação
}

Apresentei às crianças um vídeo que tratava de instrumentos musicais e, em seguida, dei-lhes a oportunidade de manusear e explorar instrumentos convencionais de diferentes materiais que foram trazidos para a sala de aula - desde aqueles encontrados com frequência nas escolas, até instrumentos de origem africana (tais como pau-de-chuva e chocalho de pé). As crianças exploraram-nos de forma livre e, após essa etapa, solicitei que cada uma escolhesse um instrumento e o experimentasse até escolher um som para ser apresentado para os colegas. Foi interessante observar a atenção, o cuidado e as possibilidades que cada criança buscou para achar um som interessante.

Em roda, cada criança apresentou o som escolhido e, posteriormente, perguntei a elas que critérios de classificação de instrumentos poderiam ser adotados para organizá-las em grupo, considerando que, em seguida, elas fariam uma composição. Uma das alunas sugeriu que fosse feita a divisão em função do tamanho dos instrumentos e as outras crianças 
concordaram. Assim, fomos reorganizando o grupo e voltamos a brincar de "Maestro", com a finalidade de criarmos uma composição coletiva.

Em outro momento, trouxe para a sala diferentes tipos de materiais (sucatas, cola tesoura, papéis coloridos) e solicitei que cada criança confeccionasse um instrumento musical. Nesse momento não tinha a intenção de trazer referências de instrumentos musicais com sucatas; deixei as crianças livres para que criassem os instrumentos do jeito que elas gostariam, explorando as sucatas, os objetos disponibilizados, o som que o objeto poderia produzir. Nesse processo, fui auxiliando, por se tratarem de crianças bem pequenas que necessitam de atenção e supervisão dos adultos quanto ao uso de tesoura, cola quente e outros materiais. Essa etapa durou alguns dias, devido à quantidade de crianças na sala de aula (32 crianças). Após todos os instrumentos prontos, foi dedicado um momento para a exploração dos sons nos instrumentos que as crianças produziram.

A culminância do projeto se deu com uma exposição dos instrumentos musicais confeccionados pelas crianças. Pais, professores, alunos de outras turmas e funcionários tiveram a oportunidade de apreciar e explorar sonoramente os instrumentos confeccionados, além de apreciar os vídeos produzidos durante o projeto e ouvir sons elaborados pelas crianças acompanhados de fotos e registros que iam aparecendo no data show.

\subsection{Avaliação do projeto}

Com a finalização do projeto, foi possível verificar que o olhar das crianças transformou-se e ampliou-se diante da música. Devido a suas falas e ações, deu para perceber que elas compreenderam que é possível produzir sons de diferentes formas e que a música não está inserida apenas nas canções do dia-a-dia ou na música que escutamos em um aparelho de $\mathrm{CD}$, mas ela está por toda parte. As vivências de exploração deram-se não apenas nos momentos em que trabalhávamos a música em si, mas na rotina delas. Lembro-me, por exemplo, de um dia em que as crianças estavam brincando com pinos mágicos e eu estava em minha mesa olhando as agendas, quando um aluno veio com alguns pinos e falou: "Olha, Prô! O som que consegui fazer com esses pinos!”, e o aluno começou a bater os pininhos que estavam na mão dele de forma ritmada. Pensei: “As crianças estão compreendendo; consegui atingir meu objetivo acerca da música com elas!”.

Além disso, outro dia, enquanto brincavam de massinha, coloquei para tocar algumas músicas instrumentais e, por coincidência, uma das músicas sonorizava o estalar dos dedos, o baterem com as mãos e, por elas mesmas, ouvindo a música, foram acompanhando, de modo a reproduzir os sons. 
No parque, elas me chamavam para falar: "Prô: você está ouvindo o som dos passarinhos?”. Isso é pensar na paisagem sonora. É estar atento aos sons do ambiente.

Pude perceber ao longo do projeto o quanto ambos, eu como professora e as crianças, aprendemos sobre música.

Finalizei o projeto com a sensação de dever cumprido: as crianças levaram consigo a música e eu, como professora, vivências demonstraram que há atividades e projetos musicais possíveis de serem desenvolvidos em sala de aula por um educador sem formação específica, desde que este se empenhe em estudar e em conhecer mais do universo e das práticas musicais.

\section{Considerações finais}

"O professor precisa permanecer uma criança (grande), sensível, vulnerável e aberto a mudanças." Murray Schafer ( p. 270)

Finalizando este trabalho, após uma trajetória em que tive a oportunidade de estudar os professores Fábio Cintra e Pedro Paulo Salles no Curso de Especialização em Linguagens da Arte, oferecido pelo Centro Universitário Maria Antônia, e de realizar um projeto voltado à prática musical junto a meus alunos de cinco e seis anos, concluo que é possível trabalhar a música na Educação Infantil. Pude verificar que, nessa etapa, a criança já está pronta pra vivenciar o universo maravilhoso da música! Ela já traz elementos primordiais para um trabalho musical interessante, pois, por si só, já vivencia um mundo lúdico, criativo, "brincante", onde ela experimenta, cria, explora...

Considerando as palavras de SCHAFER na frase acima, acredito que um professor sem formação específica consegue realizar um trabalho com a música junto às crianças, mas essa ação e esse desejo dependem inicialmente de seu esforço enquanto docente. Ele precisa querer procurar, gostar, pesquisar, ler, entender, estudar, ampliar; para que, dessa forma, a criança tenha a oportunidade de experimentar musicalmente.

Acredito que, quando um professor tem esse olhar aberto e flexível, tudo soa e acontece de forma fluida e intensa.

Já dizia Paulo Freire: "Como professor devo saber que sem a curiosidade que me move, que me inquieta, que me insere na busca, não aprendo nem ensino." (2007, p.85). Nesse sentido, um professor em constante busca do conhecimento, aprenderá e trará esse aprender à criança. No meu caso, é o que me move, é o que me cativa a cada dia dentro da sala de aula. 
$\mathrm{Na}$ parte final de meu trabalho, em que trouxe possibilidades reais de se trabalhar música em sala de aula, pude apresentar momentos nos quais as atividades junto às crianças efetivamente aconteceram. Nos momentos dedicados à organização da rotina diária da classe, os próprios alunos deram retorno, ao fazerem comentários que demonstraram os bons resultados dessa proposta, desenvolvida por uma professora sem formação específica na área.

Concluo a pesquisa reiterando que a criança está aberta ao novo e que a música pode ser trabalhada na Educação Infantil por um professor generalista, desde que este esteja em constante busca do conhecimento e disposto a criar e a trazer aos alunos práticas musicais significativas.

\section{Referências Bibliográficas}

BRASIL, Referencial Curricular nacional para a Educação Infantil: Introdução. Brasília: $\mathrm{MEC} / \mathrm{SEF}, 1998$, vol. 1.

BRITO, Teca Alencar. Música na Educação Infantil: propostas para a formação integral da criança. São Paulo: Peirópolis, 2003.

FONTERRADA, Marisa Trench de Oliveira. De tramas e fios: Um ensaio sobre a música e educação. 2 ed. Editora UNESP, 2008.

FREIRE, Paulo. Pedagogia da autonomia saberes necessário à pratica educativa. 36 ed. São Paulo: Paz Terra, 2007.

HERNANDEZ, Fernando. Cultura Visual, mudança educativa e projeto de trabalho. Porto Alegre: Artes Médicas, 2000.

KOELLREUTTER, Hans-Joachim. Prefácio In ALFAYA, Mônica \& PAREJO, Enny. Musicalizar: Uma proposta para vivência dos elementos musicais. São Paulo: Musimed, 1987.

PACHECO, Eduardo Guedes. Pedacursão: uma experiência de formação em Educação Musical na pedagogia. Cadernos de Educação | FaE/PPGE/UFPe - Pelotas [29]: 89 - 104, julho/dezembro 2007 em http://www.ufpel.edu.br/fae/caduc/downloads/n29/05.pdf, , acessado em 18 de Janeiro de 2013

SALLES, Pedro Paulo. A reinvenção da música pela criança: implicações pedagógicas da criação musical. Tese de Doutorado apresentada a Faculdade de Educação da Universidade de São Paulo-FEUSP. São Paulo, 2002.

SCHAFER, Murray. O ouvido pensante. 2a ed. São Paulo: Unesp, 2011. 
${ }^{\text {i }}$ Professora de educação Infantil na PMSP e Professora de Arte na rede estadual de SP.

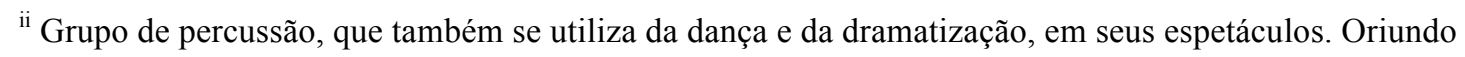
de Brighton, Reino Unido, seus integrantes usam o corpo e objetos comuns para criar performances teatrais físicas percussivas. A palavra stomp pode se referir a um subgênero distinto de teatro físico, onde o corpo incorpora-se a outros objetos como meio de produzir percussão e movimento.

iii Grupo brasileiro de percussão corporal, formado na cidade de São Paulo, que realiza pesquisa de sons corporais e vocais, aproveitando-os como elementos primordiais em suas composições e performances. 